\title{
Cocculus/Nux vomica/Tabacum/Petroleum Extract
}

National Cancer Institute

\section{Source}

National Cancer Institute. Cocculus/Nux vomica/Tabacum/Petroleum Extract. NCI

Thesaurus. Code C66805.

\begin{abstract}
A homeopathic herbal formulation with potential anti-emetic activity. Cocculus/nux vomica/tabacum/petroleum extract contains equal homeopathic units of the following extracts: extract of Cocculus indicus (fish berry), the fruit of the southeast Asian/Indian climbing plant Anamirta cocculus; extract of the seeds of Strychnos nux vomica (poison nut), an everg reen tree native to southeast Asia; extract of Nicotiana tabacum (tobacco); and petroleum. Although the exact mechanism(s) of action for this formulation has yet to be fully elucidated, alkaloids in these plant extracts have been shown to relieve nausea, vomiting, and, in some cases, dizziness.
\end{abstract}

